\title{
OS “ANIVERSÁRIOS” DAS IRMANDADES: OCASIÕES DE COMUNHÃO ESPIRITUAL ENTRE CONFRADES VIVOS E DEFUNTOS
}

\author{
THE "ANNIVERSARIES" OF THE BROTHERHOODS: SPIRITUAL COMMUNION
}

BETWEEN ALIVE AND DECEASED CONFRERES

NORBERTO FERRAZ ${ }^{*}$

\begin{abstract}
RESUMO
Neste artigo é nosso objectivo apresentar e analisar um dos momentos celebrativos fulcrais das confrarias bracarenses setecentistas: os "aniversários". Estas celebrações anuais eram variadas conforme a capacidade financeira e prestígio social de cada irmandade. Assim se algumas apenas determinavam a celebração de missas pelas almas de todos os membros da instituição, vivos e defuntos, outras prescreviam um cerimonial mais complexo, que incluía a realização de um ofício solene. Os "aniversários" eram uma ocasião única para reforçar os laços entre confrades e a união da irmandade. Simultaneamente, lembravam-se os irmãos defuntos e pediase a Deus pela sua salvação.
\end{abstract}

Palavras-Chave: Celebrações. Cerimonial. Confrarias bracarenses.

\section{ABSTRACT}

In this article is our purpose to present and analyse one of the more important celebrative moment soft he confraternities of Braga in the XVIII century: their anniversaries. These annual celebrations could vary in conformity with the financial capacity and social prestige of each brother hood. If some only determined the celebration of masses for the souls of every members of the institution, alive or deceased, others prescribed a more complex cerimonial, that included the realization of one solemn "religious function". The anniversaries were an unique ocasion to reinforce the ties between confreres and the union of the brotherhood. Simultaineously, the deceased brothers were remembered and did was asked to God their salvation.

KEYWORDS: Celebrations. Cerimonial. Confraternities of Braga.

$\mathrm{Na}$ Idade Moderna, as irmandades constituíam pólos e espaços privilegiados de interação e congregação dos homens, em nível social e religioso. Estas instituições procuravam proporcionar aos seus membros ocasiões de encontro e comunhão, através da participação em rituais e celebrações religiosas, que se inseriam frequentemente em momentos festivos solenes. Tais ocasiões podiam ter lugar por altura da comemoração do santo patrono da instituição, através da qual a confraria congregava os seus membros e assinalava à restante comunidade a sua posição e prestígio sócio-religiosos. Todavia, os

${ }^{(*)}$ Doutor em História Moderna pela Universidade do Minho/ Portugal. Licenciado e Mestre em Sociologia pela Universidade do Minho E-mail: norberto_tiago@iol.pt 
eventos agregadores dos irmãos aconteciam igualmente por motivos das festas, ritos e cerimônias onde se procurava garantir a salvação da alma. ${ }^{1}$

Na verdade as confrarias portuguesas deste período, em consonância com o espírito barroco pós-Trento, ${ }^{2}$ investiram os seus recursos em diversas manifestações festivas, cultuais e sufrágicas, de forma a incentivar a adesão das pessoas às suas fileiras, ou, pelo menos, às suas manifestações de piedade religiosa. Em face do perigo protestante era necessário que o catolicismo afirmasse a sua força religiosa nos espíritos, através de múltiplas e pomposas formas de culto e festividade, que incluíram, necessariamente, o culto das almas, reforçado pela Igreja na Época Moderna. ${ }^{3}$

Neste sentido, em Braga, as confrarias locais no século XVIII organizavam atos de celebração religiosa coletiva, com o objetivo de manter e fortalecer os laços memoriais entre os confrades vivos e defuntos 4 . O principal momento propiciador do reforço da proximidade e união celebrativas, entre os membros das organizações confraternais, era, segundo a nossa análise, a celebração do "aniversário" destas instituições.5 Esta festividade, em que se congregavam todos os irmãos, consistia numa cerimónia onde se procurava beneficiar espiritualmente as almas de todos os confrades vivos e defuntos, reforçando intemporalmente a coesão da instituição. ${ }^{6}$ Contudo, este momento de encontro entre os membros vivos e falecidos, não se processava de modo similar nas várias irmandades. O nosso estudo, inserido numa investigação mais abrangente sobre a vivência da morte e a salvação da alma na Braga setecentista, revela diferentes linhas de ação neste ponto particular. Devemos

\footnotetext{
${ }^{1}$ As festas proporcionavam "cadências regeneradoras da rotina, movimentos novos de equilíbrio ritmando o próprio conteúdo cultural envolvente, como se se tratassem de momentos obrigatórios e propícios ao rodar da vida." Leia-se sobre este assunto LIMA, 1996, p. 271.

${ }^{2} \mathrm{O}$ concílio de Trento, no século XVI, foi a resposta da Igreja Católica ao protestantismo crescente e à necessidade de reforma interna. As suas diretrizes espirituais e religiosas iriam condicionar as manifestações de culto católico nos séculos seguintes.
}

3 Veja-se ENES, p. 298; MORAES, p. 280.

4 Um dos traços fundamentais das confrarias era o sufrágio das almas dos seus confrades. Consulte-se a este propósito BRAGA, 1997, p. 449, 452; CONDE, 2005 p. 601. As Misericórdias, que eram confrarias laicas, procediam de igual modo ao sufrágio das almas dos irmãos. Para este assunto leia-se ABREU, 1990, p. 32 .

50 termo "Aniversário", para definir esta celebração em benefício de todos os irmãos, é utilizado em todas as fontes confraternais. Como veremos, ocorriam quase sempre em novembro e, por isso, distinguiam-se do dia da festa do santo protetor da instituição, ou do próprio dia da fundação da irmandade que, em muitos casos, podia até ser desconhecido.

${ }^{6}$ Nos "Aniversários" as confrarias procuravam relembrar todos os seus membros. Para este assunto consulte-se MOTA, 1987, p. 296-297. A celebração de “aniversários” estava já presente nas confrarias medievais. Relativamente a esta presença leia-se GONZÁLEZ ARCE, 2009, p. 84. 
aqui mencionar que o número de confrarias na cidade, durante o século XVIII, foi bastante assinalável, proporcionando aos habitantes um contínuo e múltiplo celebrar de cerimónias.7 Nestas instituições se procurava enquadrar uma população citadina católica, que aumentou de 14 mil habitantes para $17 \mathrm{mil}$, entre o início e o fim da centúria. ${ }^{8}$

Na irmandade de São Vicente ${ }^{9}$ os mordomos depositavam "um pano no lugar acostumado," no interior da igreja, junto ao qual era colocada uma cruz com duas velas a ladeá-la. O pano era igualmente alumiado com quatro tochas, uma em cada um dos seus ângulos. Os mordomos eram instruídos no sentido de levantar uma essa, espécie de monumento funerário que representava o local em que os corpos eram depositados antes do enterro, de modo a conferir maior solenidade à cerimónia. O “aniversário" podia incluir a celebração da hora canónica designada "vésperas," inserida na realização obrigatória de um ofício de defuntos, ${ }^{10}$ durante o qual estavam presentes vários sacerdotes. Para além do ofício, a irmandade determinava a celebração de várias missas, devendo os clérigos presentes, segundo os estatutos de 1723, ser membros da confraria. ${ }^{11}$ Todavia, nos estatutos de 1768 essa disposição foi alterada e a irmandade decidiu colocar avisos na porta da igreja, nos quais solicitava a presença de clérigos celebrantes. Esta mudança pode ter sido motivada pela pouca afluência dos sacerdotes membros da instituição. O número de sufrágios celebrado no "aniversário," inicialmente não estava prescrito, tendo sido fixado em 100, no ano de 1768. ${ }^{12}$ Deste modo, o "aniversário" de irmãos consistia num ofício solene, ${ }^{13}$ acompanhado pela celebração de várias missas na igreja, por intenção

\footnotetext{
7 Apesar de estar por fazer uma contabilidade definitiva, estudos apontam para um quantitativo acima de 80 irmandades existentes em Braga no século XVIII. CAPELA; FERREIRA, p. 194-195.

8 Leia-se BANDEIRA, 1993, p. 200,

9Esta irmandade era uma das mais prestigiadas da cidade, com grande número de confrades, dotada de forte capacidade económica e com uma igreja própria. Ainda hoje se mantém em funcionamento.

${ }^{10}$ Relembremos queo ofício consistia em leituras da Sagrada Escritura e de outros textos dos primeiros teólogos da Igreja, bem como o canto de salmos e outras orações, nas várias horas canónicas. Confira-se Enciclopedia de la religion católica,1953, p. 963-965.

${ }^{11}$ Arquivo de São Vicente doravanteAISVTE, Fundo da irmandade de São Vicente, Livro de estatutos reformados da irmandade de São Vicente, 1723, fls. 15, 20-20v., 28-30v.; Livro de estatutos reformados da irmandade de São Vicente, 1768, fls. 27v.-28.

12 AISVTE, Fundo da irmandade de São Vicente, Livro de estatutos reformados da irmandade de São Vicente, 1768 , fl. 57 .

13A confraria do Santíssimo Sacramento da vila de Cabeção celebrava um ofício noturno pela alma de todos os confrades falecidos, ao passo que a confraria do Senhor Jesus dos Passos celebrava um ofício de três lições com o mesmo fim. Leia-se BEIRANTE, 2011, p. 25. Os ofícios de três lições eram os mais simples como refere DURÃES, 2000, p. 442.
} 
dos confrades vivos e defuntos. Seria este modelo celebrativo seguido pelas suas congéneres em termos locais?

A confraria de Santo Homem Bom ${ }^{14}$ prescrevia estatutariamente, para o seu "aniversário," a celebração de um dia de missas pelos confrades vivos e defuntos, estabelecendo um teto máximo de 60 sufrágios. Á semelhança do que sucedia em São Vicente, também aqui os mordomos deviam ter preparado um pano preto para colocar defronte do altar do santo patrono, com uma cruz, dois círios a ladeá-la e quatro tochas em volta do pano. ${ }^{15} \mathrm{Um}$ pormenor distintivo desta instituição consistia na presença de uma caldeira de água benta, que os sacerdotes utilizavam para aspergir o pano, enquanto sobre ele rezavam um responso pela alma dos confrades vivos e defuntos. Ausente do cerimonial desta instituição estava a realização de um ofício. As missas eram rezadas nos altares da Sé, os quais eram previamente preparados pelos mordomos com dois cirios, vinho e hóstias. Estes indivíduos, em conjunto com outros colegas da Mesa, deviam assistir às missas, para sufragarem, com a sua presença e oração, a alma dos irmãos defuntos, cumprindo a obrigação espiritual dos irmãos vivos para com os confrades já falecidos. O cerimonial não sofreu alterações, embora na segunda metade do século XVIII, a sua celebração estivesse suspensa, enquanto a situação financeira da confraria não apresentasse melhorias. ${ }^{16}$ Apesar de querer homenagear os seus mortos, mantendo os laços entre os membros vivos e defuntos, ${ }^{17}$ suspendeu esta manifestação de solidariedade entre os dois mundos, quando os constrangimentos de ordem financeira a isso obrigaram.

$\mathrm{Na}$ verdade, algumas confrarias, possivelmente devido aos menores recursos financeiros de que dispunham, assinalavam o seu "aniversário" somente com a celebração de "missas gerais," não prevendo outra cerimónia

${ }^{14}$ Esta era a confraria dos alfaiates de Braga, sedeada na Sé Arquiepiscopal. Em 1783 uniu-se à irmandade de São Vicente.

15 Situação semelhante acontecia na irmandade de São Tomás de Aquino, uma instituição a que pertenciam os clérigos da urbe bracarense, a qual previa também a celebração de 60 missas nos altares da Sé. No centro da capela desta irmandade eram colocados os mesmos objetos que mencionámos, relativamente à irmandade de São Vicente. Os celebrantes dos sufrágios, após o seu término, vinham a este local rezar um responso. Arquivo da Faculdade de Teologia da Universidade Católica de Braga doravante AFTUCB, Fundo da irmandade de São Tomás de Aquino, Livro de estatutos da irmandade do angélico doutor São Tomás de Aquino, 1712, fls. 10, 24.

${ }^{16}$ Aparentemente, no início do século XVIII, esse teto máximo não estava estabelecido, tendo a irmandade a responsabilidade de mandar celebrar um dia de "missas gerais." AISVTE, Fundo da irmandade de Santo Homem Bom, Livro de estatutos da irmandade de Santo Homem Bom, 1688, fls. 21-22; Livro de estatutos reformados da irmandade de Santo Homem Bom, 1725, fls. 50v.-51v.; Estatutos da irmandade de Santo Homem Bom, 1773, fl. 58v.

${ }^{17}$ Sobre o sufrágio das almas dos irmãos vivos e defuntos como um traço caraterístico das instituições confraternais confira-se igualmente GOMES, 2002, p. 196-197. 
com maior pompa. Era exemplo deste cenário a confraria de Santo Amaro da Sé, que determinava a celebração de 40 sufrágios no início do século XVIII, número que aumentou para 60, em meados da centúria e para 70, no ano de 1781, por decisão estatutária. ${ }^{18} \mathrm{Na}$ mesma linha de atuação estavam as confrarias das Santas Chagas e a de São Tiago da Cividade. ${ }^{19}$ Esta última, em 1739, previa a realização de 50 missas sem outra cerimónia religiosa. No entanto, afetada por problemas financeiros, a irmandade de São Tiago viu-se constrangida, em 1775, a suspender o seu "aniversário.”2o

Se a irmandade de Santo Homem Bom determinara, como limite máximo, a celebração de 60 missas de "aniversário," a irmandade de São Crispim e São Crispiniano, ${ }^{21}$ pelo contrário, nas determinações estatutárias de 1702, impunha esse número como limite mínimo. De qualquer modo, antecipando a hipótese da impossibilidade de celebração de todos os sufrágios num único dia, estas irmandades determinavam a sua continuação no dia seguinte. ${ }^{22}$

As celebrações nas irmandades de Santa Cruz, do Bom Jesus dos Santos ${ }^{23}$ Passos, ${ }^{24}$ de Nossa Senhora do Ó do Hospital, de São Pedro dos Clérigos, das

\footnotetext{
${ }^{18}$ Arquivo da Igreja da Sé de Braga doravante AISB, Fundo da confraria de Santo Amaro da Sé, Estatutos da confraria de Santo Amaro, 1742, fl. 22; Estatutos da confraria de Santo Amaro, 1781, fls. 30v.-31.
}

${ }_{19}^{19}$ Estas confrarias estavam localizadas na igreja da freguesia da Cividade em Braga. Nas décadas de 1770 e 1790, respectivamente, uniram-se à irmandade de Santa Cruz.

${ }^{20}$ Arquivo da Igreja de Santa Cruz doravante AISC, Fundo da irmandade de São Tiago da Cividade, Livro
de estatutos da confraria do apóstolo São Tiago da igreja da Cividade, 1739, fl. 26v., 51; Livro das
certidões das missas e assentos de irmãos $1603-1794$, fls. 530, 532v., 534v.-535. A confraria das Santas
Chagas, no início do século XVIII, determinava a celebração de missas gerais sem fixar um quantitativo.
Posteriormente, em 1740, prescreveu a celebração de 60 sufrágios, número que aumentou para 100, quatro
anos depois. Contudo, face às despesas que este aumento acarretava e à situação financeira da instituição,
em 1752 estabeleceu a celebração de 50 missas. AISC, Fundo da irmandade das Santas Chagas da Cividade,
Estatutos da confraria das Santas Chagas da Cividade, 1719, fl. 196v.; Estatutos da irmandade das
Santíssimas Chagas, 1740, não paginado;Livro das missas dos irmãos defuntos e legados da confraria
das Chagas, 1695-1794, fls. 6-6v., 38-42, 83-88, 116v.-129, 169-171v., 360v., 471-474v.

${ }^{21} \mathrm{~A}$ irmandade de São Crispim englobava os sapateiros da cidade.

22 Foi apenas nos estatutos de 1731 que ficou explicitamente determinada, na irmandade de São Crispim e São Crispiniano, a obrigação de os mordomos colocarem o pano preto, ladeado da cruz, círios e tochas, bem como da caldeira para os responsos. Para além disso, estes homens tinham de preparar os altares com as hóstias, vinho e velas necessários às celebrações. É possível que fosse já esta a prática antes de 1731, mas só neste ano ficou confirmada nos estatutos. AISB, Fundo da irmandade de São Crispim e São Crispiniano, Livro de estatutos da irmandade de São Crispim e São Crispiniano, 1702, fl. 16v.; Livro de estatutos da irmandade de São Crispim e São Crispiniano, 1731, fls. 33-33v. Como podemos constatar, estes procedimentos cultuais eram comuns aos estatutos de diversas irmandades locais.

23Esta confraria era dotada de forte poder financeiro. Esteve localizada na igreja do convento do Pópulo até à década de 1720, transferindo-se posteriormente para a igreja de Santa Ana. Em 1772 uniu-se à de Santa Cruz.

24 A irmandade do Bom Jesus dos Santos Passos, depois de sair do convento do Pópulo no início da década de 1720, deixou de fazer o ofício, do qual estavam encarregues os frades do referido convento, bem como a construção da essa, trabalho a cargo dos mordomos. O "aniversário" passou a consistir somente na 
Almas de São Vítor, das Almas da Sé, das Almas de São Vicente e das Almas de São João da Ponte, pelo contrário, aproximavam-se do modelo seguido pela irmandade de São Vicente, pois incluíam a celebração de um ofício, para além das missas. ${ }^{25} \mathrm{Na}$ irmandade das Almas da Sé, os mordomos edificavam um túmulo, ou essa, levantado no interior da igreja, pela ocasião do "aniversário,” o qual, nas palavras dos estatutos, devia ser ornamentado conforme "a necessidade e não a vaidade". Patenteia-se nesta passagem uma crítica ao exagero barroco, que transformava uma cerimónia de piedade, numa manifestação de orgulho exibicional das instituições confraternais.

A celebração do "aniversário" nesta confraria começava na véspera, com um ofício mandado celebrar pelas almas dos defuntos. Na manhã do dia seguinte, tinha lugar uma missa solene cantada, com sermão, a qual era encerrada com uma procissão em honra dos defuntos. ${ }^{26}$ Durante todo o dia, os altares estavam prontos com os objetos litúrgicos necessários, para que os sacerdotes aí celebrassem outros sufrágios. O seu número era variável, consoante a afluência de sacerdotes e as possibilidades financeiras da irmandade. O trabalho de preparação dos altares para esta celebração cabia ao servo da instituição. Este, numa alteração estatutária de 1776, ficou incumbido igualmente de acender as velas que ornamentavam a essa, edificada pelos mordomos. ${ }^{27}$ Apesar dos alertas nos primeiros estatutos, verificámos que, posteriormente, os mesários terão caído em gastos excessivos na ornamentação da essa. ${ }^{28}$ Nesse sentido, a reforma estatutária de 1776 determinou o limite

celebração de missas. Na década de 1720 esta confraria chegou a mandar celebrar 200, 300 e posteriormente 600 missas nesta ocasião, celebradas certamente durante alguns dias. Estava de facto ao arbítrio da Mesa, o número de sufrágios a realizar. Na década de 1730 determinou-se a celebração de três dias de missas gerais. Depois desta década, o "aniversário" parece ter sido suspenso pela instituição. AISC, Fundo da irmandade do Bom Jesus dos Santos Passos, Livro de estatutos da irmandade do Bom Jesus dos Passos, 1707, fls. 20v., 46-46v.; Livro dos termos de mesa e juntas e aceitação de irmãos da irmandade dos Santos Passos, 1686-1740, fls. 495v., 510, 518v., 556, 563, 572; Livro das despesas da irmandade do Bom Jesus dos Santos Passos, 1628-1772, fls. 490-496v., 524-527v., 593v.-598v., 617v.-621v., 669v.-673v.

25 Por outro lado, algumas confrarias parecem não ter sequer previsto esta festividade de comunhão entre confrades vivos e defuntos. Eram os casos das confrarias de São Bento do convento do Salvador, de Nossa Senhora da Boa Memória e a de Nossa Senhora do Bom Despacho.

${ }^{26}$ A comemoração do "aniversário" da Misericórdia de Ponte de Lima, para além do ofício e missa cantada, incluía uma procissão pelo adro da igreja da irmandade. Para esta confraria confira-se ARAÚJO, 2000, p. 530.

27 AISB, Fundo da confraria das Almas da Sé, Estatutos da confraria das Almas da Sé desta cidade, 1723, fls. $6 \mathrm{v} ., 7 \mathrm{v} ., 28$.

${ }^{28} \mathrm{O}$ cuidado com a ornamentação deste objeto não foi apenas apanágio das confrarias bracarenses. No século XVIII, a essa do "aniversário" da Ordem Terceira de São Paulo era colocada sobre uma alcatifa. À sua volta ardiam várias velas em castiçais de prata. Ramalhetes de flores adornavam o monumento e figuras representando a morte lembravam a todos o fim comum de qualquer homem. A este propósito veja-se MORAES, 2009, p. 540. 
máximo de 32 velas para alumiar a essa. ${ }^{29}$ Inicialmente, esta irmandade celebrava o seu "aniversário" entre os dias 28 e 29 de novembro, sendo mais tarde tudo alterado para os dias cinco e seis do mesmo mês, de forma a coincidir com o oitavário do dia de Fiéis de Deus. ${ }^{30}$ Segundo os registos documentais, esta confraria tinha, em algumas ocasiões, tentado celebrar o seu "aniversário" num único dia. Todavia, como este só podia começar depois do coro da Sé ter rezado as horas canónicas, os responsáveis da irmandade constataram a hora tardia do seu começo, com repercussão no número de fiéis presentes, uma vez que ficavam apenas os elementos da confraria e alguns sacerdotes a assistir ao ofício e à posterior procissão. ${ }^{31}$ É evidente que, para a projeção social e religiosa da confraria, esta era uma situação inconveniente, e por isso, estabeleceu a sua realização durante dois dias.

A regulamentação estatutária da confraria das Almas de São João da Ponte $^{32}$ era mais precisa na descrição do seu "aniversário." Este decorria na última semana de novembro,33 consistindo num ofício de nove lições,34 celebrado por dez padres, aos quais cabia igualmente dizer, cada um, uma missa na capela da irmandade. $35 \mathrm{O}$ ofício incluía a celebração de uma missa cantada pelo pároco da freguesia. No fim desta, havia uma procissão em torno da capela. 36

Durante o decurso do dia, de modo similar ao que sucedia noutras irmandades, a capela tinha os seus altares iluminados e apetrechados com vinho e hóstias. Com o objetivo de obter o maior número possível de celebrações

\footnotetext{
${ }^{29}$ Sobre a celebração do "aniversário” na confraria das Almas da Sé consulte-se igualmente CAPELA, 2003, p. 195 .

30 As Misericórdias comemoravam a quadra de Todos-os-Santos e Fiéis Defuntos através de um "Aniversário" com sufrágios pelas almas dos irmãos vivos e defuntos, bem como pelos benfeitores. Era uma festa religiosa solidária entre o mundo dos vivos e dos mortos.

${ }^{31}$ AISB, Fundo da confraria das Almas da Sé, Estatutos da confraria das Almas da Sé desta cidade, 1723, fls. 14-15v., 30v.- 31

32Estava localizada numa pequena capela dedicada a São João Batista nos arredores da cidade.

33Na segunda metade do século XVII, o “aniversário" dos irmãos defuntos da Ordem Terceira de São Francisco do Porto era no próprio dia de Todos-os-Santos. Veja-se JESUS, 2006, p. 73.
}

$34 \mathrm{O}$ ofício de nove lições era o mais importante, pois incluía um maior número de leituras, de recitação de salmos e outras orações.

35A Misericórdia bragantina, no século XVII, celebrava uma missa e um ofício de nove lições por cada irmão defunto. Leia-se sobre este aspeto CASTRO, 1948, p. 210-212.

${ }^{36}$ Esta confraria, apesar de mandar celebrar um ofício, não previa a edificação de uma essa. Arquivo da Igreja de São Lázaro doravante AISL, Fundo da confraria das Almas de São João da Ponte, Estatutos da confraria das Almas de São João da Ponte, desta cidade de Braga, 1784, fls. 11-11v. 
eucarísticas, a confraria solicitava a presença de outros clérigos, para celebrarem mais sufrágios.

Por seu turno, a confraria das Almas de São Vítor37 optou por fazer um plano celebrativo inverso. A celebração das missas gerais decorria nos dias antecedentes à realização do ofício. Quando este se iniciava, no dia principal do “aniversário,” a celebração dos sufrágios cessava, para não causar "perturbação” durante o ofício e o sermão. Deste modo, na segunda-feira depois do oitavário do dia de Todos-os-Santos, celebrava-se um ofício, que incluía o canto da hora canónica "vésperas" a cantochão, pelas almas do Purgatório. ${ }^{8} \mathrm{Na}$ terça-feira, a festividade prosseguia com uma missa cantada com sermão, celebrados após a oração da hora canónica, designada por "laudes," com a qual se encerrava o ofício. Todos os mesários, envergando as suas becas e de tochas na mão, tinham obrigatoriamente de estar presentes. 39

A irmandade de Nossa Senhora do Ó40 incluía igualmente, no seu "aniversário," a realização de um ofício e a celebração de missas nos altares da igreja do hospital, já devidamente preparados para o efeito. ${ }^{41}$ Aos mordomos era determinada a edificação da essa, à semelhança do que sucedia noutras instituições congéneres. O “aniversário" desta irmandade tinha lugar no oitavário do dia de Fiéis de Deus e iniciava-se com a celebração de "vésperas," no dia anterior, à tarde. No dia seguinte, a celebração prosseguia com a reza das horas canónicas "matinas" e "laudes." 42 Terminada a celebração das horas

\footnotetext{
37 Fundada em 1704 ficou sedeada na igreja da freguesia de São Vítor da cidade de Braga.

38 No oitavário do dia de Todos-os-Santos, a confraria do Corpo Santo do Funchal celebrava um ofício de nove lições, com vésperas. Este ato religioso era não só em benefício das almas dos confrades defuntos, como também de suas esposas e filhos. Em relação a este aspeto veja-se VERİSSIMO, 1992, p. 118.

390 "aniversário" desta irmandade incluía o levantamento do túmulo ou essa. Arquivo da Igreja de São Víctor doravante AISV, Fundo da irmandade das Almas de São Vítor, Livro de estatutos da confraria das Almas de São Vítor, 1738, fls. 12, 17-17v.

${ }^{40}$ Estava situada na igreja do hospital. Na segunda metade do século XVIII uniu-se à confraria de Nossa Senhora-a-Branca.

${ }^{41}$ Os sufrágios eram celebrados no próprio dia do "aniversário" ou no dia seguinte, estando colocado no meio da igreja o pano preto, com a cruz, as tochas e a caldeira. Cada sacerdote, no fim de celebrar a sua missa, devia rezar um responso e lançar água benta sobre o pano. AISV, Fundo da irmandade de Nossa Senhora do Ó do Hospital, Estatutos reformados da confraria de Nossa Senhora do Ó, 1701, fls. 11v.-13.

${ }^{42}$ A Misericórdia da Póvoa de Varzim celebrava o seu “aniversário," pelos confrades vivos e defuntos, com início no quarto domingo de novembro, continuando na segunda-feira. No domingo realizavam-se as vésperas e matinas e no dia seguinte havia missa com sermão. Leia-se DIONİSIO, 2005, p. 183.
} 
canónicas do ofício, tinha lugar uma missa com pregação, concluindo-se a comemoração do "aniversário" com uma procissão pelos defuntos. 43

Da análise da documentação das confrarias estudadas, existem duas que se destacaram pelo cuidado na elaboração, na atenção aos detalhes e na solenidade que colocavam na celebração deste momento festivo: eram a irmandade de São Pedro dos Clérigos44 e a de Santa Cruz. A primeira realizava o "aniversário" pelos irmãos vivos e defuntos, nos dias 12 e 13 de novembro, que consistia num ofício de defuntos, solenizado com canto, música e sermão. No dia 12, cantavam-se as horas canónicas "vésperas" e "matinas" e, no dia seguinte, a cerimónia continuava com o canto das horas canónicas "laudes," 45 seguidas de uma missa cantada e sermão. Era o secretário da confraria quem estava incumbido de orientar o ofício e posteriormente, cantar a missa. O ofício celebrava-se na capela e era acompanhado pelo toque dos sinos da catedral, assinalando a realização desta cerimónia, uma referência que apenas encontrámos nos estatutos desta confraria. ${ }^{46}$ Este facto não deixa de nos colocar algumas questões. O toque dos sinos não perturbaria a celebração do ofício? Seria executado de modo a poder coadjuvar-se com o cerimonial e não ser um fator desestabilizador? Ou apenas teria lugar em determinados momentos da celebração?

À semelhança das suas congéneres, esta irmandade determinava a celebração de missas gerais, fixando o seu número em 100 sufrágios. As celebrações decorriam na capela de São Geraldo da Sé e nos altares do respetivo claustro.47 Para fazer face a um número de sufrágios tão avultado, os responsáveis da instituição foram flexíveis, permitindo a sua celebração durante o oitavário seguinte à realização do “aniversário.” Estas missas tinham de ser todas ditas pelos irmãos sacerdotes da confraria, os quais eram coadjuvados por

\footnotetext{
43AINSB, Fundo da irmandade de Nossa Senhora do Ó do Hospital, Estatutos reformados da confraria de Nossa Senhora do Ó, 1701, fls. 11v.-13, 27.

44 Esta era a principal irmandade de sacerdotes em Braga. Localizava-se na capela de São Geraldo na Sé.

45 As horas canónicas vésperas, matinas e laudes eram as mais importantes, designadas por horas "maiores". As vésperas eram celebradas ao pôr-do-sol, as matinas de madrugadae as laudes ao início da manhã. É por esta razão que os ofícios de "aniversário" se concentravam sobretudo nestas três horas. Em cada um destes momentos rezavam-se orações, cantavam-se salmos e liam-se leituras da Bíblia. Veja-se sobre este assunto Enciclopedia de la religion católica,1953, p. 963-965.
}

46 AISC, Fundo da irmandade de São Pedro dos Clérigos, Estatutos da irmandade de São Pedro dos Clérigos, 1739, pp. 59-60, 80-81.

47 Na Santa Casa da Misericórdia de Braga, por ocasião do “aniversário," eram celebradas missas gerais para além do ofício. Consulte-se CASTRO, 2006, p. 576. 
um mesário, ${ }^{48}$ bem como por quatro irmãos leigos, encarregados da preparação dos altares e de disponibilizarem as alfaias religiosas necessárias à celebração das eucaristias. 49

Esta celebração festiva exigia a participação de todos os irmãos, fossem eclesiásticos ou leigos. As suas faltas eram penalizadas com multas de 50 réis. $\mathrm{E}$ não era apenas a sua presença que era requerida. Os confrades deviam comparecer na cerimónia de modo digno. Assim, os irmãos leigos estavam obrigados a envergar as opas da irmandade, ao passo que os sacerdotes compareciam revestidos das suas sobrepelizes, com barretes na cabeça5o e trazendo os livros necessários para poderem seguir e acompanhar os rituais da cerimónia. ${ }^{1}$ Ao determinar a presença obrigatória de todos os seus membros, a irmandade tentava demonstrar a sua coesão interna face à comunidade. Por outro lado, o grande número de confrades presentes concedia maior aparato e pompa a esta festa confraternal, prestigiando-a e distinguindo-a aos olhos dos fiéis. Deste modo, promovia-se o prestígio da irmandade e estimulava-se a adesão de novos elementos.

Apesar do "aniversário" da irmandade de São Pedro dos Clérigos ser já uma celebração mais detalhada e faustosa, pensamos, contudo, que a irmandade de Santa Cruz $^{52}$ procedia a um cerimonial que, entre as confrarias analisadas, foi o que mais se destacou pela sua pompa e solenidade. Na primeira quinta-feira, após o dia de Fiéis Defuntos, 53 começava o sino a tocar chamando os irmãos ao ofício, inicialmente para a celebração das "vésperas" e depois para a de "matinas." A estes momentos celebrativos assistiam todos os irmãos

\footnotetext{
${ }^{48}$ Devemos mencionar que não encontrámos celebrações confraternais especificamente dirigidas em benefício da alma dos mesários. Neste aspeto todos os confrades eram tratados por igual.

49 Ou seja, com o vinho, a cera e as hóstias, como vimos anteriormente.

50 Em relação à necessidade dos sacerdotes se apresentarem dignamente vestidos com sobrepelizes e barretes nas funções religiosas, em particular naquelas em favor dos defuntos confira-se FARIA, 2006,p. 788; SOARES, 1997, p. 534-535. A sobrepeliz é uma veste litúrgica utilizada pelos clérigos quando assistem em diversas celebrações litúrgicas, como os ofícios.

51 AFTUCB, Fundo da irmandade de São Pedro dos Clérigos, Estatutos da irmandade de São Pedro dos Clérigos, 1739, pp. 26, 59, 60, 76, 80-81.

${ }^{52} \mathrm{~A}$ irmandade de Santa Cruz foi fundada em 1581. No século XVII tornou-se uma confraria de grande prestígio à qual aderiam as elites locais. Mantem-se em funcionamento, sendo hoje dona de um lar de idosos, um jardim de infância, para além de tomar parte na organizaçãoda Procissão do Enterro em sextafeira santa.

53 No século XVI, o "aniversário" da Santa Casa da Misericórdia de Lisboa era celebrado no dia de São Martinho. Leia-se sobre este assunto SÁ, 2001, p. 91-92. Pela mesma altura, as confrarias de Bolonha determinavam a celebração de uma missa anual por todos os seus membros falecidos. Consulte-se sobre esta missa anual TERPSTRA, 1995, p. 72.
} 
sacerdotes, envergando as suas sobrepelizes. Os capelães do coro ajudavam na cerimónia, através do canto, mas se faltassem ao ofício, o que só poderia acontecer por um motivo que fosse considerado legítimo pela irmandade, deviam rezá-lo em sua casa.54

No dia seguinte, bem cedo, a celebração prosseguia. Os irmãos eram novamente convocados pelo repique dos sinos. Os mordomos deviam ter preparada a "essa," ou túmulo levantado, no meio da igreja, alumiada pelas velas consideradas necessárias. Eram, então, celebradas as "laudes," inseridas no ofício de nove lições, bem como "três nocturnos" 55 com música. 56 Uma vez concluído o ofício, celebrava-se uma missa cantada, onde o celebrante principal era coadjuvado por um diácono e um sub-diácono. Durante a celebração era feita uma pregação solene aos presentes, aludindo-se à importância dos sufrágios para a salvação das almas que estavam no Purgatório, justificando, deste modo, a celebração do "aniversário." Por fim, os clérigos presentes rodeavam a essa levantada, para rezarem um responso por alma dos confrades defuntos. Os mordomos deviam ter os altares da igreja prontos para as missas gerais, normalmente celebradas na ocasião. Por determinação dos estatutos de 1702 o número de sufrágios não podia ser inferior a 60. As regulamentações estatutárias posteriores fixaram esse valor específico, como sendo o número de sufrágios a celebrar por ocasião do "aniversário." 57 Os altares da igreja estavam ornamentados com panos pretos. Os irmãos presentes na cerimónia estavam obrigados a envergar as vestes da instituição e a todos se pedia que rezassem uma "coroa" por alma dos colegas, mesmo que não participassem no “aniversário." 58 A celebração concluía-se com uma procissão, na qual os irmãos presentes se deviam incorporar. Esta procissão aparece mencionada nos estatutos de 1702 e 1762, mas neles não se descreve o seu decurso. Todavia, os estatutos de 1664 eram mais detalhados neste ponto:

\footnotetext{
54 AISC, Fundo da irmandade de Santa Cruz, Livro de estatutos da irmandade de Santa Cruz, 1664, 1702, 1762, 1773, fls. 280v.,-281, 386v.-388, 488-489.

55Segundo Rafael Bluetau um noturno é uma das três partes em que geralmente se divide a hora canónica matinas, com um certo número de salmos e leituras. BLUTEAU, 1712, p. 733. Para Maria Manuela Rodrigues, um noturno era composto por três lições (leituras). Consulte-se RODRIGUES, 1991, p. 167.

${ }^{56} \mathrm{O}$ "aniversário" da Ordem Terceira prolongava-se por dois dias, à semelhança do verificado em Santa Cruz e incluía a celebração das horas canónicas, vésperas, matinas e laudes. A este propósito confira-se MORAES, 2009, p. 310-313.

57AISC, Fundo da irmandade de Santa Cruz, Livro de estatutos da irmandade de Santa Cruz, 1664, 1702, 1762, 1773, fls. 280v.-281, 386v.-388.

58 AISC, Fundo da irmandade de Santa Cruz, Livro de estatutos da irmandade de Santa Cruz, 1664, 1702, 1762, 1773, fls. 280v.,-281, 386v.-388, 488-489.
} 
[...] Para esta procissão deve a irmandade dar tochas aos irmãos e se dará uma volta ao campo direito á esquina do hospital de São Marcos que fica ao poente aonde estão sepultados muitos desamparados e aí dirá a primeira oração por seu adro e a outra defronte da igreja velha de Santa Cruz que é hoje a nova do hospital e se lançará água benta no cemitério do hospital que está no campo a face da parede e na igreja e pátio do hospital e no terreiro publico que fica ao nascente do lado da igreja do hospital na parte do qual esteve a igreja velha e no dito caminho publico jazem alguns nossos irmãos e se lançará água benta se lhe dirá um responso e se usará com eles esta misericórdia em cada um ano já que por razão da mudança da igreja se não pode fazer mais vezes, e por todos os que jazem e para memoria da dita mudança e feito isto se virá a irmandade recolhendo e depois de entrar se dirá o ultimo responso com a solenidade devida. 59

Constatamos que a irmandade de Santa Cruz pretendia manter os laços de comunhão com os confrades mais antigos, que tinham ficado sepultados numa zona de uma antiga igreja, aparentemente depois convertida em caminho público, ${ }^{60}$ mantendo viva uma ligação espiritual que devia permanecer para lá dos constrangimentos do espaço e do tempo. A manutenção desses laços memoriais entre confrades, era reforçada pelo gesto simbólico e cultual do lançamento de água benta sobre as suas sepulturas localizadas fora de um templo religioso. Este gesto era igualmente uma manifestação de esperança na sua salvação eterna.

Por outro lado, o facto de os confrades se dirigirem a um local onde estavam sepultados “muitos desamparados," junto ao hospital da Misericórdia, parece indicar-nos que, pelo menos nesta época, a irmandade de Santa Cruz tinha a preocupação de se associar aos que rogavam pelas almas dos mais pobres. ${ }^{61}$

A celebração do "aniversário" manteve-se, com ligeiras alterações, nos estatutos de 1762. Nessa data, foi decidido que o capelão-mor devia capitular o ofício, acompanhado pelos capelães do coro nas funções de acólitos. ${ }^{62}$ As regras estatutárias de 1773 determinaram uma mudança importante: a procissão final

\footnotetext{
59AISC, Fundo da irmandade de Santa Cruz, Livro de estatutos da irmandade de Santa Cruz, 1664, 1702, 1762, 1773, fls. 191v.-192.

${ }^{60} \mathrm{~A}$ irmandade de Santa Cruz esteve inicialmente sedeada num altar da igreja de São Marcos, do hospital da Misericórdia. Veja-se COSTA, 1993, p. 14

${ }^{61}$ A Santa Casa da Misericórdia de Braga enterrava os pobres e as crianças enjeitadas no claustro de Santo Amaro da Sé, mas também possuía um cemitério privado onde enterrava os que faleciam no seu hospital.

62 Os capelães da Misericórdia do Funchal tinham a obrigação de assistir ao ofício do "aniversário" da instituição. Sobre esta obrigação leia-se JARDIM, 1997, p. 37-41.
} 
passou a desenrolar-se somente dentro da igreja. ${ }^{63}$ Como se justifica esta mudança? A Misericórdia teria vedado o acesso à zona sob seu controlo? Ou na segunda metade do século XVIII, a irmandade já não sentira necessidade de recordar, com a sua presença física no local onde tinham ficado sepultados, as almas daqueles confrades que tinham partido há mais tempo? Não temos respostas seguras, mas não podemos deixar de assinalar esta alteração importante.

Em 1788 o “aniversário," tal como vinha sendo preceituado estatutariamente, foi abolido. A presença de poucos clérigos na cerimónia, factor que diminuía o seu prestígio e esplendor acabou por ditar o seu fim. Os próprios irmãos leigos aderiam cada vez menos a esta celebração. Por isso, os responsáveis da irmandade decidiram que esta festividade constasse apenas de 80 missas nos altares da igreja, pagas a 120 réis e celebradas durante o oitavário de Todos-os-Santos. Eram colocados editais na porta da igreja, no sentido de convocar os clérigos da cidade para irem rezar estas missas. 64 Este recuo na celebração do "aniversário" levanta-nos algumas questões. A que se terá ficado a dever a falta de adesão, não só dos clérigos como também dos próprios irmãos? A duração dos atos cerimoniais seria um fator dissuasor da sua presença? Na verdade, o "aniversário" da irmandade era uma cerimónia longa que englobava dois dias. 65

Por outro lado, já em 1781, houvera um corte nos gastos com a essa. É possível que, para além de uma menor adesão dos capelães e dos confrades, existissem também dificuldades financeiras que contribuíram para esta alteração. ${ }^{66}$ Para além destes aspetos, no século XVIII, a igreja esteve em obras por várias ocasiões, o que levou à não celebração do "aniversário" na forma prevista pelos estatutos, durante alguns anos. ${ }^{67}$ A ocorrência destes trabalhos pode, do mesmo modo, ter retirado meios financeiros para o fazer. É portanto

\footnotetext{
63AISC, Fundo da irmandade de Santa Cruz, Livro de estatutos da irmandade de Santa Cruz, 1664, 1702, 1762, 1773, fl. 489 .

64AISC, Fundo da irmandade de Santa Cruz, Livro de estatutos da irmandade de Santa Cruz, Bom Jesus dos Santos Passos e Santa Ana, 1788, fl. 71.

65 o "aniversário" da confraria das Almas de Sepúlveda incluía uma vigília ao fim do primeiro dia e a celebração de uma missa com sermão no segundo. Era edificada uma tumba alumiada com velas dentro da igreja. Leia-se a este respeito CONDE, 2008, p. 140.

66 AISC, Fundo da irmandade de Santa Cruz, Livro de termos de mesa e de junta da irmandade de Santa Cruz, 1772-1790, fl. 363v.

67 AISC, Fundo da irmandade de Santa Cruz, Livro de termos de mesa e de junta da irmandade de Santa Cruz, 1772-1790, fl. 18.
} 
possível que estas interrupções tenham contribuído para diluir o costume, entre os confrades, de celebrarem este evento conforme estava previsto.

Em várias confrarias, como mencionámos, o número de missas de "aniversário" estava determinado nas regras estatutárias. Mas, noutras instituições, não existia uma indicação precisa. Constatámos que o seu volume variou ao longo dos anos. Nem sempre o número de sufrágios celebrados era quantificado. Por vezes, existiu somente a referência à celebração de um ou dois dias de missas gerais. Ou seja, celebravam-se os sufrágios possíveis durante esses dias, conforme as disponibilidades financeiras da confraria e a afluência de sacerdotes. Analisemos então, alguns exemplos da evolução da quantidade de sufrágios no “aniversário," nas confrarias em estudo.

Os dados relativos à irmandade das Santas Chagas mostram-nos que o número de missas celebradas nas primeiras décadas do século XVIII foi variável, tendo estabilizado na década de 1740, em 100 sufrágios. Este valor representou uma enorme subida, face às cerca de 20 missas que eram rezadas 20 anos antes. 68 É possível que a diminuição dos preços, associada a uma situação financeira mais desafogada, tivesse permitido este aumento exponencial. ${ }^{69}$ Contudo, na década de 1750, o número caiu para metade, sem que as fontes nos indiquem o motivo. É provável que a confraria enfrentasse já dificuldades de ordem económico-financeira que justificassem este corte. $\mathrm{O}$ posterior aumento do custo dos sufrágios pode ter também contribuído para esta redução. A não alteração do número de missas, a partir da década de 1750, parece significar que os responsáveis da instituição definiram como sendo este, na prática, o número de sufrágios a efetuar, ainda que os estatutos não o determinassem.

Por seu turno, os dados disponíveis relativos à irmandade de São Vicente confirmam que o número de 100 missas, definido pelos estatutos de 1768, foi efetivamente cumprido pelos responsáveis da instituição. Apesar da alteração de preços, que correspondeu a uma subida significativa do custo destes sufrágios, a instituição parecia ter ainda, nas últimas décadas de setecentos, meios para

\footnotetext{
${ }^{68}$ Vinte missas era o número de sufrágios celebrado pela confraria do Espírito Santo de Ponte de Lima, por ocasião do "aniversário" comemorado perto do dia de Fiéis Defuntos, em meados do século XVIII. Veja-se relativamente a este número ARAÚJO, 2001/2002, p. 465.

${ }^{69} \mathrm{Na}$ Misericórdia de Ponte da Barca, os sufrágios pelas almas dos confrades defuntos eram pagos a 80 no início do século XVIII, a 100 réis em 1750 e a 120 réis por volta de 1771 . Consulte-se sobre este preçário PEREIRA, 2008, p. 245.
} 
manter inalterável o número de missas que mandava rezar por ocasião do seu “aniversário,” com que se comprometera em 1768.70

Na documentação compulsada relativa à confraria das Almas de São Vítor, foi igualmente possível estudar a variação da quantidade de missas de “aniversário," celebradas ao longo dos anos, incluindo nesta análise o preço e o número de dias em que decorreram. Assim, até 1750, o número de missas celebrado ultrapassava a centena. De facto, na década de 1730, os sufrágios ditos eram na ordem de várias centenas. ${ }^{71}$ Em 1731, a instituição conseguiu celebrar seis dias de missas gerais, o que resultou em mais de 500 missas celebradas. ${ }^{72}$ A esta pujança, seguiu-se uma quebra acentuada, depois de 1750. Na década de 1770, o número de missas celebrado decaiu, mas apresentou uma recuperação na década de 1780 . O volume destes sufrágios não estava fixado estatutariamente, dependendo, em parte, de um peditório de esmolas efetuado na cidade e nos arredores, para a sua celebração. Apesar de termos verificado uma redução nos valores arrecadados nestes peditórios na década de 1770, eles possibilitavam ainda assim a celebração de mais sufrágios do que os verificados. Como estava situada na zona limítrofe da cidade, a irmandade pode ter sentido, por vezes, algumas dificuldades na atração de celebrantes. Tal problema seria mais evidente, se esta comemoração coincidisse com idênticas celebrações das

\footnotetext{
${ }^{70} \mathrm{~A}$ irmandade de São Crispim e São Crispiniano também pôde manter o mesmo grau celebrativo de missas gerais, nesta ocasião festiva. Tendo começado, no início do século XVIII, por celebrar geralmente entre 60 a 70 sufrágios, fixou-se posteriormente no número de 60 missas, em conformidade com os preceitos estatutários, que determinavam esse valor como sendo a bitola mínima a atingir. Do mesmo modo que sucedeu noutras instituições congéneres, o preço pago pelos sufrágios subiu de 80 réis, praticados no início do século, para 120, já na última década setecentista. AISB, Fundo da irmandade de São Crispim e São Crispiniano, Livro de estatutos da irmandade de São Crispim e São Crispiniano, 1702, fl. 16v.; Livro de estatutos da irmandade de São Crispim e São Crispiniano, 1731, fl. 33v.; Livro de missas dos irmãos defuntos da irmandade de São Crispim e São Crispiniano, 1689-1719, não paginado; Livro de missas dos irmãos defuntos da irmandade de São Crispim e São Crispiniano, 1740-1758, fls. 2-8v., 35-42, 69-76, 114-121; Livro de missas dos irmãos defuntos da irmandade de São Crispim e São Crispiniano, 1758-1798, fls. 10v.-17v., 49-55v., 81v.-85v., 111v.-114v., 137v.-145, 169-171v., 194-200v., 218-223.
}

${ }^{71}$ São valores bastante assinaláveis, pois em 1740 foram ditas 200 missas de "aniversário" na Santa Casa da Misericórdia de Braga. Veja-se a este respeito CASTRO, 2006, p. 327.

${ }^{72}$ Em 1728, a irmandade do Bom Jesus dos Santos Passos, mandou celebrar 600 missas de "aniversário," as quais decorreram em várias igrejas. A irmandade decidiu proceder deste modo para compensar o facto de, por ter saído do convento do Pópulo, sua sede, não poder mandar mandar celebrar os ofícios que estavam contratualizados com os frades desta instituição. AISC, Fundo da irmandade do Bom Jesus dos Santos Passos, Livro de termos de mesa e juntas e aceitação de irmãos da irmandade dos Santos Passos, 1686-1740, fl. 518v. 
confrarias do centro da cidade, as quais teriam maior facilidade na captação de sacerdotes. 73

É de assinalar e relembrar que as missas gerais do "aniversário" desta irmandade não eram celebradas apenas em favor das almas dos seus irmãos, mas sufragavam também todas as restantes almas do Purgatório.74 Ou seja, tinham um âmbito que ia para além do mero contexto confraternal.Por isso, eram sufrágios apelativos para toda a população que quisesse contribuir com as suas esmolas, pois o benefício espiritual que proporcionavam servia também às almas dos seus familiares e amigos. Verificámos também que o preço dos sufrágios era relativamente mais elevado, em comparação com as outras organizações confraternais. É possível que, como esta confraria estava situada numa zona mais distante do centro da cidade, confinando com o mundo rural, os clérigos exigissem maior pagamento pelo trabalho de celebração na igreja de São Vítor. Deste modo, os responsáveis da instituição terão constatado a necessidade de elevar o preçário, de forma a poderem contar com sacerdotes disponíveis para a prestação deste serviço. 75

Também a confraria de Nossa Senhora do Ó, no dealbar do século XVIII, procedia à edificação da essa na celebração do "aniversário." Contudo, devido às despesas que esta cerimónia acarretava, bem como por causa dos conflitos do capelão da irmandade com o pároco da igreja de São João de Souto, a instituição, a breve trecho, cingiu-se somente à celebração de um dia de missas gerais, sem número fixo. Nesta irmandade constatamos a tendência para a descida, a partir de meados da década de 1740, do número de sufrágios. Apesar de se verificar esta evolução, por vezes, existiram anos em que se registou uma subida, como se verificou em 1755 e 1760. Todavia, em 1752, foram celebradas somente cinco missas. Em sentido inverso, em 1737, foram celebradas 108

73AISV, Fundo da irmandade das Almas de São Vítor, Livro de termos de mesa da confraria das Almas de São Vítor, 1752-1776, fl. 310v.; Livro de termos de mesa da irmandade das Almas de São Vítor, 1776-1794, fl. 121.

74 AISV, Fundo da irmandade das Almas de São Vítor, Livro de estatutos da confraria das Almas de São Vítor, 1738 , fls. 17-17v.

75 Entre finais da década de 1760 e 1787, o número de missas de "aniversário" da confraria das Almas de São João de Ponte variou entre 10 a 30 sufrágios. Os preços estiveram num intervalo entre os 120 e os 150 réis. Entre 1787 e 1800 o número de sufrágios variou entre um mínimo de 12, em 1791 e um máximo 71 missas, em 1800. A tendência foi, portanto, de subida. Neste período de tempo, os preços oscilaram sobretudo entre os 140 e 180 réis, mas existiram casos excecionais de algumas missas celebradas a 240 e uma até por 370 réis, demonstrando o grau de dificuldade existente, em algumas ocasiões, para a irmandade encontrar celebrantes. AISL, Fundo da confraria das Almas de São João da Ponte, Livro de registo das certidões das missas da confraria das benditas Almas de São João da Ponte, 1767-1802, fls. 1$85 \mathrm{v}$. 
missas. Esta variação dependia provavelmente da capacidade financeira da confraria, em cada ano, bem como da afluência à igreja de clérigos celebrantes. Simultaneamente, os preços praticados que tinham começado por ser de 100 réis na década de 1730 , sofreram uma redução, baixando para 80 réis nas de 1740 e 1750. A partir dos meados do século XVIII, voltaram a subir para 100 réis, atingindo posteriormente os 120 no ano de 1770, pouco antes da confraria ser anexada à irmandade de Nossa Senhora-a-Branca.

Desta forma, no que diz respeito ao número de missas celebradas no "aniversário," as confrarias bracarenses seguiram duas vias. Enquanto umas fixaram nos seus estatutos um número determinado, outras decidiram fazer depender o volume de celebrações das possibilidades financeiras e humanas de cada ano. A este facto não deve ser também alheia a própria lei de oferta e procura relativamente aos clérigos celebrantes, os quais tenderiam a comparecer em maior número se o pagamento dos sufrágios aumentasse, conforme referimos anteriormente. Mergulhadas num clima competitivo, no qual procuravam atrair a estas celebrações o maior número possível de religiosos, as organizações confraternais viram-se constrangidas a elevar os preçários praticados, relativamente aos sufrágios celebrados. E se algumas, mais robustas financeiramente, puderam manter o nível de sufrágios prestados, apesar do aumento de preços, outras foram compelidas a reduzir o volume de missas celebradas.

Este ponto relaciona-se também com o facto de, na maior parte das confrarias que estudámos, estas festas por alma de todos os confrades se celebrarem durante o mês de novembro, ${ }^{76}$ período de tempo dedicado à lembrança e sufrágio das almas dos defuntos. 77 Não estaremos longe da verdade se afirmarmos que era perfeitamente possível suceder a coincidência da celebração dos "aniversários" de algumas confrarias, nos mesmos dias, ou dias muito próximos. Um cenário desta natureza era favorável à criação de um clima

\footnotetext{
${ }^{76}$ Era recorrente no mundo confraternal moderno a celebração deste evento ocorrer em novembro.

77 Nas confrarias das Santas Chagas, de Santo Homem Bom e de São Crispim, o aniversário decorria por ocasião da festa do santo patrono da instituição. AISB, Fundo da irmandade de São Crispim e São Crispiniano, Livro de estatutos da irmandade de São Crispim e São Crispiniano, 1701, fl. 16v.; Livro de estatutos da irmandade de São Crispim e São Crispiniano, 1731, fl. 33; AISC, Fundo da irmandade das Santas Chagas da Cividade, Livro dos estatutos da confraria das Santas Chagas, 1719, fl. 196v.; Estatutos da irmandade das Santíssimas Chagas da igreja de São Tiago da Cividade, 174O, não paginado; AISVTE, Fundo da irmandade de Santo Homem Bom, Livro de estatutos reformados a irmandade de Santo Homem Bom, 1725, fl. 50v. Em Espanha, as irmandades de Nossa Senhora do Rosário preferiam celebrar os "aniversários" por ocasiões das festividades marianas. A este propósito leia-se MANTECÓN MOVELLÁN, 1990, p. 101.
} 
de competição entre irmandades, procurando cada uma atrair o maior número de sacerdotes às suas cerimónias, oferecendo maiores pagamentos. Na verdade, constatámos em alguns casos ter-se verificado um aumento do preço das missas pagas pelas confrarias, ao longo dos dias da celebração do "aniversário.” Esta situação sucedia quando compareciam poucos sacerdotes, obrigando estas associações a aumentar as despesas, para que acorressem em maior número a celebrar os sufrágios. 78

De qualquer modo é igualmente importante referenciar que o contexto nacional económico na segunda metade do século é de crise, com a diminuição das remessas de ouro brasileiro e o ainda muito incipiente desenvolvimento industrial português. No caso específico da região bracarense devemos lembrar que as décadas finais da centúria são marcadas por crises de produção, que fizeram encarecer o pão, alimento base da população. Era portanto natural um reflexo na subida do custo dos sufrágios. 79

Apesar de serem celebrações destinadas a promover o bem espiritual de todos os irmãos e a reforçar os laços entre vivos e defuntos, a presença dos confrades era sobretudo solicitada para o ofício, para a missa cantada e para o sermão, quando estes tinham lugar. Esperava-se, contudo, que assistissem a algumas das restantes missas, com o fim de rezar pelas almas dos irmãos já falecidos, mas também para meditar sobre as suas vidas e o seu sentimento de pertença à irmandade. Aos mordomos das confrarias cabia, por seu turno, estarem obrigatoriamente presentes durante toda a cerimónia, tendo por obrigação de assistir às missas celebradas, de modo a sufragar as almas dos confrades, para além de se certificarem da sua efetiva realização. ${ }^{80}$ Eram dias de intensa atividade cultual e espiritual, que condicionava o quotidiano dos fiéis e a sua relação com o além.

Uma questão que se nos coloca é a de justificar a celebração de tantos sufrágios em poucos dias. Este cenário pode ser explicado mais facilmente, se tivermos em conta a situação sócio religiosa vivida na época. Em primeiro lugar,

\footnotetext{
${ }^{78}$ AISL, Fundo da confraria das Almas de São João da Ponte, Livro de termos de mesa da confraria das Almas de São João da Ponte, 1726-1757, fls. 45v., 56v. 59; Livro de termos de mesa da confraria das Almas de São João da Ponte, 1757-1786, fls. 30; AISV, Fundo da irmandade das Almas de São Vítor, Livro de termos de mesa da confraria das Almas de são Vítor, 1752-1776, fls. 139v., 157, 295; Livro de termos de mesa da irmandade das Almas de São vítor, 1776-1794, fl. 195v.

79Confira-se ABREU, 1997, p. 29-30, 184; LOPES, 2002, p. 80.

${ }^{80} \mathrm{~A}$ celebração anual de atos religiosos em novembro, por alma dos seus membros falecidos tinha igualmente lugar na Ordem Terceira de A Grana, em Espanha. A este propósito veja-se MARTÍN GARCÍA, 2004, pp. 516-517.
} 
a presença de um grande número de clérigos na cidade no século XVIII proporcionava a celebração desta quantidade de sufrágios. ${ }^{81} \mathrm{Em}$ seguida, devemos recordar que estas missas podiam ter lugar simultaneamente em vários altares das igrejas, previamente preparados, o que possibilitava um maior número de celebrações. Para além destes fatores, devemos igualmente referir a hipótese de estes sufrágios serem celebrados de forma relativamente rápida, o que possibilitava a sua realização em maior quantidade. ${ }^{82}$

A análise da celebração do "aniversário," nas confrarias bracarenses, confirma que esta era uma ocasião propícia para o reforço dos laços de união entre os confrades vivos e defuntos, mantendo a solidariedade da "família confraternal." Relembrar anualmente as almas dos irmãos defuntos da irmandade e pedir pela sua salvação em conjunto com as dos irmãos vivos, era manter viva a história da instituição e conceder-lhe um sentido de continuidade ao longo dos tempos. Esta cerimónia proporcionava uma comunhão religiosa e sufrágica entre as almas dos irmãos vivos e falecidos. Ao pedirem a Deus a salvação do Purgatório, das almas dos colegas já falecidos, os membros vivos das confrarias procediam a um ato de piedade, em benefício da sua própria alma. As almas cativas neste lugar, podiam efetivamente atuar como intercessoras dos vivos diante de Deus. Mas, para algumas confrarias, as razões que fundamentavam a realização destes eventos, estavam associadas a outros motivos: o "aniversário" tornava-se ocasião propícia para uma celebração solene e pomposa, na qual se procedia à exaltação do prestígio social e religioso da própria confraria.

\section{REFERÊNCIAS}

ABREU, José Paulo.Em Braga de 1790 a 1805: D. Frei Caetano Brandão: o reformador contestado. Braga: Universidade Católica Portuguesa; Faculdade de Teologia de Braga: Cabido Metropolitano e Primacial de Braga, 1997.

ABREU, Laurinda.A Santa Casa da Misericórdia de Setúbal de 1500 a 1755: aspectos de sociabilidade e poder. Setúbal: Santa Casa da Misericórdia de Setúbal, 1990.

ARAÚJO, Maria Marta Lobo de.Dar aos pobres e emprestar a Deus: as Misericórdias de Vila Viçosa e Ponte de Lima (séculos XVI-XVIII). Barcelos:

\footnotetext{
${ }^{81}$ Leia-se CAPELA, 2002, p. 170-171. No início do século XVIII estima-se que existiram perto de 300 clérigos na cidade de Braga. CAPELA; FERREIRA, 2002, pp. 170-171.

${ }^{82}$ Algumas missas, na arquidiocese, efetivamente, eram celebradas de modo tão rápido que, em 1793, o arcebispo D. Frei Caetano Brandão proibiu a celebração de qualquer eucaristia em menos de 20 minutos. Consulte-se ABREU, 1997, p. 231.
} 
Santa Casa da Misericórdia de Vila Viçosa; Santa Casa da Misericórdia de Ponte de Lima, 2000.

ARAÚJO, M. M. L. de. A ajuda aos pobres nas confrarias de Nossa Senhora da Guia e do Espirito Santo de Ponte de Lima (séculos XVII a XIX).Bracara Augusta, Braga, vol. L, p. 441-468, 2001/2002.

BANDEIRA, Miguel Sopas. O espaço urbano de Braga em meados do século XVIII. Geografia Revista da Faculdade de Letras da Universidade do Porto, Porto I série, vol. IX, p. 138-207, 1993.

BEIRANTE, Maria Ângela.As antigas confrarias da vila de Cabeção: espelho da sua vida social e religiosa. Cabeção: Edição de autor, 2011.

BLUTEAU, Raphael.Vocabulário Portuguez e Latino, tomo V. Coimbra: no Colégio das Artes da Companhia de Jesus, 1712.

BRAGA, P. D. Uma confraria da Inquisição. A irmandade de São Pedro Mártir (breves notas). Arquipélago - História,Ponta Delgada, 2ª série, II, p. 449- 458, 1997.

CAPELA, José Viriato; FERREIRA, Ana da Cunha.Braga Triunfante (Braga nas Memórias Paroquiais de 1758). Braga: Universidade do Minho, 2002.

CAPELA, José Viriato.As freguesias do distrito de Braga nas memórias paroquiais de 1758: a construção do imaginário minhoto setecentista. Braga: s/n, 2003.

CASTRO, José de.A Santa e Real casa da Misericórdia de Bragança. Lisboa: Tipografia da União Gráfica, 1948.

CASTRO, Maria de Fátima.A Misericórdia de Braga. Assistência material e espiritual (Das origens a cerca de 1910), vol. III. Braga: Santa Casa da Misericórdia de Braga e autora, 2006.

CASTRO, Maria de Fátima.A Misericórdia de Braga. A assistência no hospital de São Marcos, volume IV. Braga: Santa Casa da Misericórdia de Braga e autora, 2006.

CAPELA, José Viriato; FERREIRA, Ana da Cunha.Braga Triunfante (Braga nas Memórias Paroquiais de 1758).Braga: Universidade do Minho, 2002.

CONDE, José António Linage. Outra cofradia de Sepulveda absorbida por el corpus: animas. In I Congresso nacional de las cofradias sacramentales. Minerva. Liturgia, fiesta y fraternidade en el barroco espanhol.Sepúlveda (Segóvia):Cofradíadel Corpus de Sepulveda, 2008, p. 133-169.

CONDE, Manuel Sílvio Alves. A confraria de Santa Cruz de Tomar (1470). Arquipélago - História,Ponta Delgada, $2^{\mathrm{a}}$ série, IX, p. 601-620, 2005.

COSTA, Luís.O templo de Santa Cruz.Braga: Edição da Irmandade de Santa Cruz, 1993. 
DIONÍSIO, Paula Carolina. A Santa Casa da Misericórdia da Póvoa de Varzim: assistência e caridade numa vila piscatória. Póvoa de Varzim: Câmara Municipal da Póvoa de Varzim, 2005.

DURÃES, Margarida.Herança e Sucessão. Leis, Práticas e Costumes no Termo de Braga (séculos. XVIII-XIX), Tomo II. Braga, 2000.

Enciclopedia de la religion católica, Tomo V. Barcelona:Dalmau y jovierediciones, 1953.

ENES, Maria Fernanda. As confrarias do Santíssimo e das Almas no âmbito da cultura barroca (um caso na diocese de Angra). In I Congresso Internacional do Barroco, Actas, vol. I. Porto: Reitoria da Universidade do Porto e Governo Civil do Porto, 1991, pp. 275-298.

FARIA, I. M. de. A Igreja e o povo na vida e na morte séculos XVIII a XX (estudo com base em visitas pastorais e testamentos). NW, Noroeste. Revista de História, Congresso Internacional de História Territórios, Culturas e Poderes, Actas,Braga, vol. I,p. 785-802, 2006.

GOMES, P. A. de C.Oficiais e confrades em Braga no tempo de Pombal (Contributos para o estudo do movimento e organização confraternal bracarenses no século XVIII).Braga, 2002.

GONZÁLEZ ARCE, José Damián.Gremios y confrarías en los reinos medievales de León y Castillasiglos XII-XV.Palencia: Región Editorial, 2009.

JARDIM, Maria Dina dos Ramos.A Santa Casa da Misericórdia do Funchal no século XVIII. Coimbra: Centro de Estudos de História do Atlântico; Secretaria Regional do Turismo e Cultura, 1997.

JESUS, E. S. M. de.Poder, caridade e honra: o recolhimento do Anjo do Porto(1672-1800). Porto, 2006.

LIMA, J. da S. A festa religiosa no Minho. Aspectos antropológicos e pastorais. Theológica,Braga, II série, vol. XXXI, fasc. 2, p. 271-284, 1996.

LOPES, Maria Antónia.As Misericórdias de D. José ao final do século XX. In PAIVA, José Pedro (dir.).Portugalia e Monumenta Misericordiarum. Lisboa:Centro de Estudos de História Religiosa; União das Misericórdias, 2002, pp. 79-117.

MANTECÓN MOVELLÁN, Tomás Antonio.Contrarreforma y religiosidade popular em Cantabria. Las cofradias religiosas.Cantabria:Universidad de Cantabria, 1990.

MARTÍN GARCÍA, Alfredo.Religión y sociedad em Ferrolterra durante el AntiguoRégimen. La V. O. T. seglar franciscana.Estudios Mindonienses,Salamanca, $\mathrm{n}^{0}$ 20, p. 395-602, 2004.

MORAES, J. de M..Viver em penitência: os irmãos terceiros franciscanos e as suas associações, Braga e São Paulo (1672-1822). Braga, 2009. 
MOTA, Guilhermina. A irmandade da Senhora do Carmo da Marmeleira - Mortágua: primeira metade do século XVIII.Revista de História das Ideias. O sagrado e o Profano, Coimbra,n ${ }^{0}$ 9, p. 267-306, 1987.

PEREIRA, Maria das Dores Sousa.Entre ricos e pobres: a actuação da Misericórdia de Ponte da Barca 163o-18oo. Braga: Santa Casa da Misericórdia de Ponte da Barca, 2008.

RODRIGUES, M. M.Morrer no Porto durante a época barroca: atitudes e sentimento religioso. Porto, 1991.

SÁ, Isabel dos Guimarães.As Misericórdias Portuguesas de D. Manuel I a Pombal. Lisboa: Livros Horizonte, 2001.

SOARES, Franquelim Neiva.A Arquidiocese de Braga no século XVII. Sociedade e mentalidades pelas visitas pastorais (1550-1700). Braga: Universidade do Minho, Governo Civil de Braga, 1997.

VERÍSSIMO, Nelson. A confraria do Corpo Santo no século XVIII. Islenha,Funchal, $\mathrm{n}^{\mathrm{0}}$ 10, p. 116-124, 1992. 